Article

\title{
Cytotoxic, Apoptosis-Inducing Activities, and Molecular Docking of a New Sterol from Bamboo Shoot Skin Phyllostachys heterocycla var. pubescens
}

\author{
Reda F. A. Abdelhameed ${ }^{1}\left(\right.$, , Mohamed S. Nafie ${ }^{2}\left({ }^{1}\right.$, Ahmed K. Ibrahim $^{1}$, Koji Yamada ${ }^{3}$, \\ Maged S. Abdel-Kader ${ }^{4, *}$, A Amany K. Ibrahim ${ }^{1}$, Safwat A. Ahmed ${ }^{1}$, Jihan M. Badr ${ }^{1}$ \\ and Eman S. Habib ${ }^{1}$ \\ 1 Department of Pharmacognosy, Faculty of Pharmacy, Suez Canal University, Ismailia 41522, Egypt; \\ omarreda_70@yahoo.com (R.F.A.A.); ahmedkhider1993@gmail.com (A.K.I.); \\ amany_mohamed@pharm.suez.edu.eg (A.K.I.); safwat_ahmed@pharm.suez.edu.eg (S.A.A.); \\ jihanbadr2010@hotmail.com (J.M.B.); emansnd@yahoo.com (E.S.H.) \\ 2 Department of Chemistry, Faculty of Science, Suez Canal University, Ismailia 41522, Egypt; \\ mohamed_nafie@science.suez.edu.eg \\ 3 Garden for Medicinal Plants, Graduate School of Biomedical Sciences, Nagasaki University, \\ Bunkyo-machi 1-14, Nagasaki 852-8521, Japan; kyamada@nagasaki-u.ac.jp \\ 4 Department of Pharmacognosy, College of Pharmacy, Prince Sattam Bin Abdulaziz University 173, \\ Al-Kharj 11942, Saudi Arabia \\ * Correspondence: mpharm101@hotmail.com; Tel.: +966-545539145
}

Received: 15 November 2020; Accepted: 28 November 2020; Published: 30 November 2020

\begin{abstract}
Phytochemical screening of nonpolar fractions from the methanol extract of the Bamboo shoot skin Phyllostachys heterocycla var. pubescens resulted in the isolation of a new sterol-glucoside-fatty acid derivative (6'-O-octadeca- $8^{\prime \prime}, 11^{\prime \prime}$-dienoyl)-sitosterol-3-O- $\beta$-D-glucoside (1), together with six known compounds. The chemical structures of the pure isolated compounds were deduced based on different spectral data. The isolated compounds were assessed to determine their cytotoxic activity, and the results were confirmed by determining their apoptotic activity. Compound 1 was more cytotoxic against the MCF-7 cells $\left(\mathrm{IC}_{50}=25.8 \mu \mathrm{M}\right)$ compared to Fluorouracil (5-FU) $(26.98 \mu \mathrm{M})$, and it significantly stimulated apoptotic breast cancer cell death with 32.6-fold (16.63\% compared to 0.51 for the control) at pre-G1 and G2/M-phase cell cycle arrest and blocked the progression of MCF-7 cells. Additionally, RT-PCR results further confirmed the apoptotic activity of compound 1 by the upregulation of proapoptotic genes (P53; Bax; and caspases 3, 8, and 9) and downregulation of the antiapoptotic genes (BCL2). Finally, the identified compounds, especially $\mathbf{1}$, were found to have high binding affinity towards both tyrosine-specific protein kinase (TPK) and vascular endothelial growth factor receptor (VEGFR-2) through the molecular docking studies that highlight its mode of action.
\end{abstract}

Keywords: apoptosis; cytotoxic activity; Phyllostachys heterocycle; molecular docking; RT-PCR

\section{Introduction}

Bamboo is a widespread plant around the world. It comprises about 75 genera and 1250 species [1]. Bamboo young shoots are delicious and can be consumed either fresh or fermented or even canned. The shoots accumulate a considerable amount of minerals, including potassium, calcium, zinc, manganese, iron, chromium, and copper, in addition to relatively lower amounts of phosphorus and selenium [2]. Fresh shoots are reported as a good source of thiamine and niacin, besides vitamins A, B6, and E [3]. Previous studies on the medicinal activities of bamboo leaves have 
reported their antibacterial properties [4]. Moreover, bamboo species are commonly used in folk medicine for their antipyretic and anti-inflammatory, as well as diuretic, effects [3]. The therapeutic use of bamboo leaves for treating arteriosclerosis, hypertension, cardiovascular disease, and cancer have been also reported [5]. Additionally, antioxidant and angiotensin-converting enzyme inhibition activity were also proven [6,7]. A chemical investigation of different bamboo species reported the isolation of phenolic compounds [8-10] and lignans [11], besides volatile compounds [12]. Previous studies demonstrated extracts from different parts of bamboo with different chemical compositions and promising antioxidative, anticancer, antibacterial, and antiallergic activities $[13,14]$. Some fractionated compounds from bamboo were previously screened for their anticancer activities with apoptosis induction, among which was a porphyrin photosensitizer that was extracted from bamboo leaves, and induced apoptotic cell death in human leukemia CMK-7 and colon adenocarcinoma Colo320 DM cell lines by caspase-3 activation and DNA cleavage [15].

Tyrosine-specific protein kinase (TPK) is overexpressed in solid tumors and initiate its proliferation, so the escalation of drugs inhibiting TPK contributes as a significant insight in cancer treatment. The blocking of the vascular endothelial growth factor receptor (VEGFR-2) signaling pathway has become an appealing approach in the therapy of different cancer types [16]. Accordingly, TPK and VEGFR-2 are chosen as the biological targets for implementing the docking studies for the pure isolated compounds. These studies endeavor to demonstrate the binding affinity of these compounds inside TPK and VEGFR-2, define the important residues for the stabilization of ligands in the receptor active sites, and to find out their possible modes of action. Therefore, the current work focuses on moso bamboo shoot skins (Phyllostachys heterocycla var. pubescens), where the nonpolar fraction of the methanolic extract was investigated for the main chemical constituents. The chemical structures of the isolated compounds were proven, and the identified compounds were screened for their cytotoxic activity and selectivity towards cancer and normal cell lines, with apoptotic investigation for the most active compound. Additionally, the mode of action was proposed through the molecular docking studies towards TPK and VEGFR-2.

\section{Results and Discussion}

\subsection{Structure Elucidation of the Isolated Compounds}

Compound 1 was isolated as dark-yellowish waxy material. The structure of compound $\mathbf{1}$ (Figure 1) was proven to be a sterol-glucoside-fatty acid derivative, as deduced from the combined NMR and mass spectroscopic data. Extensive examination of ${ }^{1} \mathrm{H} N \mathrm{NR}$ and ${ }^{13} \mathrm{C}$ NMR spectral data, together with the data of ${ }^{1} \mathrm{H}-{ }^{1} \mathrm{H}$ COSY, DEPT, HSQC, and HMBC experiments, allowed the establishment of a C-29 steroidal skeleton with a C-5/C-6 double-bond, as indicated from the two signals resonating at $\delta_{\mathrm{C}} 141.0$ and 121.8 , respectively. ${ }^{1} \mathrm{H}$ NMR revealed a multiplet resonating at $\delta_{\mathrm{H}} 3.88$ attributed to $\mathrm{H}-3$ with its corresponding carbon detected at $\delta_{C} 78.8$ in the ${ }^{13} \mathrm{C}$ NMR spectrum, confirming a glycoside link at this position. Combined NMR spectral data (Table 1), together with a comparison with those previously published, proved the skeleton of sitosterol-3-O- $\beta$-D-glucoside [17]. The remaining signals in the ${ }^{1} \mathrm{H}$ NMR and ${ }^{13} \mathrm{C}$ NMR spectra suggested the presence of long-chain unsaturated fatty acids with four $\mathrm{sp}^{2}$ carbons detected at $\delta_{C} 128.3,128.4,130.3$, and 130.4, while the signal detected at $\delta_{C} 173.5$ confirmed the presence of ester carbonyl functionality. The site of attachment of the aliphatic chain to glucose was determined to be through an ester bond at C- $6^{\prime}$. This was based on the downfield shift of the C-6' to $\delta_{C} 64.7$ and the upshift of $C-5^{\prime}$ to $\delta_{C} 75.0$ [18]. HMBC correlation between the $\mathrm{H}_{2}-6^{\prime}$ resonating at $\delta_{\mathrm{H}} 4.76$ and the signal detected at $\delta_{\mathrm{C}} 173.5$ assigned to the carbonyl functionality $\left(\mathrm{C}-1^{\prime \prime}\right)$ further supported the position of the fatty acid moiety. ${ }^{13} \mathrm{C}$ NMR values of the allylic methylene carbons C-7", C-10", and C-13" were determined at $\delta_{C} 27.6,25.9$, and 27.5, respectively. This was based on the HMBC experiment, which correlated H-8", H-9", H-11", and H-12" $\left(4 \mathrm{H}, \mathrm{m}, \delta_{\mathrm{H}} 5.46\right)$ to C-7" $\left(\delta_{\mathrm{C}} 27.6\right)$, C-10" $\left(\delta_{C} 25.9\right)$, and C-13" $\left(\delta_{C} 27.5\right) .{ }^{1} \mathrm{H}-{ }^{1} \mathrm{H}$ COSY and HSQC experiments allowed the assembly of the $C-6 " / C-14$ " unit, as indicated in Table 1 and Figure 2. 


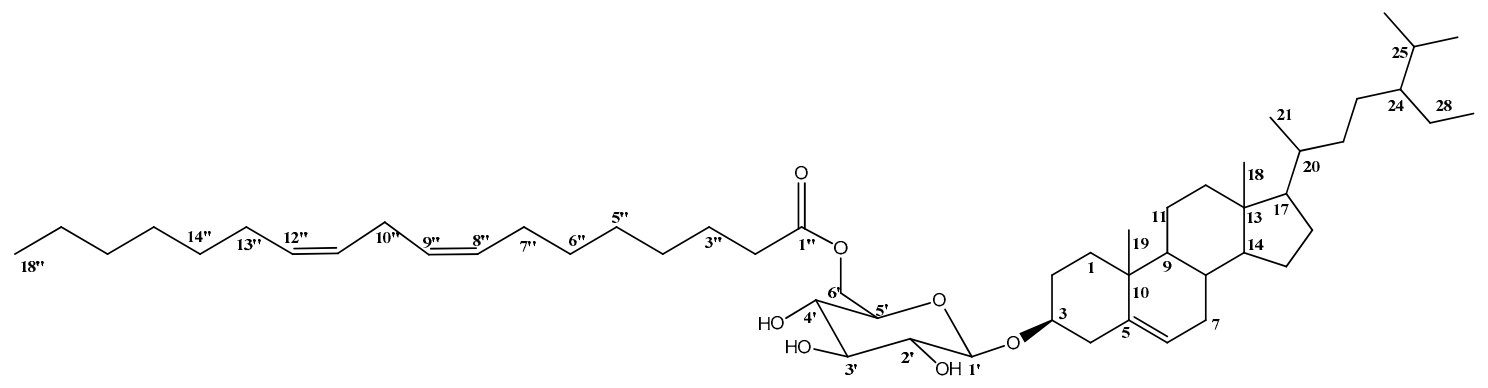

Figure 1. Structure of compound 1.

Table 1. NMR spectroscopic data of $\mathbf{1}\left(\mathrm{C}_{5} \mathrm{D}_{5} \mathrm{~N}, 500\right.$ and $\left.125 \mathrm{MHz}\right)$.

\begin{tabular}{|c|c|c|c|}
\hline Position & $\delta_{C}(m)^{a}$ & $\delta_{\mathrm{H}}(\mathrm{m}, J$ in $\mathrm{Hz})$ & Selected HMBC ${ }^{b}$ \\
\hline 1 & $37.7, \mathrm{CH}_{2}$ & $1.09,1.78$ & C-19 \\
\hline 2 & $32.1, \mathrm{CH}_{2}$ & 1.44 * & \\
\hline 3 & $78.8, \mathrm{CH}$ & $3.88, \mathrm{~m}$ & $\mathrm{C}-1^{\prime}$ \\
\hline 4 & 39.3, $\mathrm{CH}_{2}$ & $2.64, \mathrm{dd}, J(12,4), 2.43, \mathrm{brt}, J(8)$ & $C-2, C-3, C-5, C-6, C-10$ \\
\hline 5 & $141.0, \mathrm{C}$ & & \\
\hline 6 & $121.8, \mathrm{CH}$ & $5.37, \mathrm{~m}$ & $C-4, C-8, C-10$ \\
\hline 7 & $31.7, \mathrm{CH}_{2}$ & $1.48,1.91$ & C-5 \\
\hline 8 & $32.1, \mathrm{CH}$ & 1.27 & C-9, C-11, C-14 \\
\hline 9 & $50.5, \mathrm{CH}$ & $0.94 * *$ & C-1, C-5 \\
\hline 10 & $36.9 \mathrm{C}$ & & \\
\hline 11 & 21.4, $\mathrm{CH}_{2}$ & $1.44 *$ & \\
\hline 12 & $40.1, \mathrm{CH}_{2}$ & $2.05,1.27$ & \\
\hline 13 & $42.5 \mathrm{C}^{2}$ & & \\
\hline 14 & $56.9, \mathrm{CH}$ & $1.01, \mathrm{~m}$ & \\
\hline 15 & 24.6, $\mathrm{CH}_{2}$ & $1.09,1.61$ & \\
\hline 16 & 28.6, $\mathrm{CH}_{2}$ & $2.12, \mathrm{~m}$ & \\
\hline 17 & $56.3, \mathrm{CH}$ & 1.15 & \\
\hline 18 & $12.0, \mathrm{CH}_{3}$ & $0.72, \mathrm{~s}$ & C-12, C-17 \\
\hline 19 & $19.3, \mathrm{CH}_{3}$ & $0.94, \mathrm{~s}$ & C-1, C-5 \\
\hline 20 & $36.5, \mathrm{CH}$ & $1.44 *$ & \\
\hline 21 & $19.1, \mathrm{CH}_{3}$ & $1.01, \mathrm{~d}, J(6.0)$ & \\
\hline 22 & $34.2, \mathrm{CH}_{2}$ & $1.09,1.42$ & C-17, C-21 \\
\hline 23 & $26.4, \mathrm{CH}_{2}$ & 1.27 & \\
\hline 24 & $46.1, \mathrm{CH}$ & 1.01 & \\
\hline 25 & $29.5, \mathrm{CH}$ & $1.27^{* * *}$ & \\
\hline 26 & $19.4, \mathrm{CH}_{3}$ & $0.87^{* * * *}$ & \\
\hline 27 & $20.0, \mathrm{CH}_{3}$ & $0.90^{* *}$ & \\
\hline 28 & $23.4, \mathrm{CH}_{2}$ & $1.29 * * *$ & \\
\hline 29 & $12.2, \mathrm{CH}_{3}$ & $0.88^{* * * *}$ & \\
\hline $1^{\prime}$ & $102.7, \mathrm{CH}$ & $4.91, \mathrm{~d}, J(7.2)$ & $\mathrm{C}-3, \mathrm{C}-3^{\prime}$ \\
\hline $2^{\prime}$ & $75.0, \mathrm{CH}$ & $3.97, \mathrm{~d}, J(8.1)$ & $C-1^{\prime}, C-3^{\prime}$ \\
\hline $3^{\prime}$ & $78.2, \mathrm{CH}$ & $4.17, \mathrm{~m}$ & C- $4^{\prime}$ \\
\hline $4^{\prime}$ & $71.6, \mathrm{CH}$ & $3.97, \mathrm{~m}$ & $C-3^{\prime}$ \\
\hline $5^{\prime}$ & $75.0, \mathrm{CH}$ & $3.96, \mathrm{~m}$ & $C-1^{\prime}, C-3^{\prime}$ \\
\hline $6^{\prime}$ & 64.7, $\mathrm{CH}_{2}$ & $4.76, \mathrm{~m}$ & C-1" \\
\hline $1^{\prime \prime}$ & $173.5 \mathrm{C}^{2}$ & & \\
\hline $2^{\prime \prime}$ & $34.5, \mathrm{CH}_{2}$ & $2.37, \mathrm{~m}$ & C-1", C-3", C-4" \\
\hline $3^{\prime \prime}$ & $25.4, \mathrm{CH}_{2}$ & $1.65, \mathrm{~m}$ & $C-1^{\prime \prime}, C-2^{\prime \prime}, C-4^{\prime \prime}, C-5^{\prime \prime}$ \\
\hline $4^{\prime \prime}$ & $29.5-32.1, \mathrm{CH}_{2}$ & $1.32, \mathrm{~m}$ & \\
\hline $5^{\prime \prime}$ & $29.5-32.1, \mathrm{CH}_{2}$ & $1.32, \mathrm{~m}$ & \\
\hline $6^{\prime \prime}$ & $29.5-32.1, \mathrm{CH}_{2}$ & $1.32, \mathrm{~m}$ & \\
\hline $7 "$ & 27.6, $\mathrm{CH}_{2}$ & $2.12, \mathrm{~m}$ & C-5", C-6", C-8", C-9" \\
\hline $8^{\prime \prime}$ & $128.3, \mathrm{CH}$ & $5.46, \mathrm{~m}$ & C-6", C-7", C-10" \\
\hline $9^{\prime \prime}$ & $128.4, \mathrm{CH}$ & $5.46, \mathrm{~m}$ & C-7", C-10" \\
\hline $10^{\prime \prime}$ & $25.9, \mathrm{CH}_{2}$ & $2.93, \mathrm{t}, J(6.4)$ & $\mathrm{C}-8^{\prime \prime}, \mathrm{C}-9^{\prime \prime}, \mathrm{C}-11^{\prime \prime}, \mathrm{C}-12^{\prime \prime}$ \\
\hline $11^{\prime \prime}$ & $130.3, \mathrm{CH}$ & $5.46, \mathrm{~m}$ & $\mathrm{C}-10^{\prime \prime}, \mathrm{C}-13^{\prime \prime}$ \\
\hline
\end{tabular}


Table 1. Cont.

\begin{tabular}{cccc}
\hline Position & $\delta_{\mathrm{C}}(\mathbf{m})^{\mathbf{a}}$ & $\mathcal{\delta}_{\mathrm{H}}(\mathrm{m}, \boldsymbol{J} \mathbf{~ i n ~} \mathrm{Hz})$ & Selected HMBC $^{\mathbf{b}}$ \\
\hline $12^{\prime \prime}$ & $130.4, \mathrm{CH}$ & $5.46, \mathrm{~m}$ & $\mathrm{C}-10^{\prime \prime}, \mathrm{C} 13^{\prime \prime}, \mathrm{C}-14^{\prime \prime}$ \\
$13^{\prime \prime}$ & $27.5, \mathrm{CH}_{2}$ & $2.12, \mathrm{~m}$ & \\
$14^{\prime \prime}$ & $29.5-32.1, \mathrm{CH}_{2}$ & $1.32, \mathrm{~m}$ & \\
$15^{\prime \prime}$ & $29.5-32.1, \mathrm{CH}_{2}$ & $1.32, \mathrm{~m}$ & \\
$16^{\prime \prime}$ & $29.5-32.1, \mathrm{CH}_{2}$ & $1.32, \mathrm{~m}$ & \\
$17^{\prime \prime}$ & $29.5-32.1, \mathrm{CH}_{2}$ & $1.32, \mathrm{~m}$ & \\
$18^{\prime \prime}$ & $14.3, \mathrm{CH}_{3}$ & $0.87^{* * * *}$ & $\mathrm{C}-14^{\prime \prime}, \mathrm{C}-15^{\prime \prime}$ \\
\hline
\end{tabular}

${ }^{\mathrm{a}}$ Multiplicities were deduced from multiplicity-edited HSQC. ${ }^{\mathrm{b}}$ HMBC correlations are from proton(s) stated to the indicated carbons. ${ }^{*}, * * * * *$, and ${ }^{* * * *}$ overlapped signals.

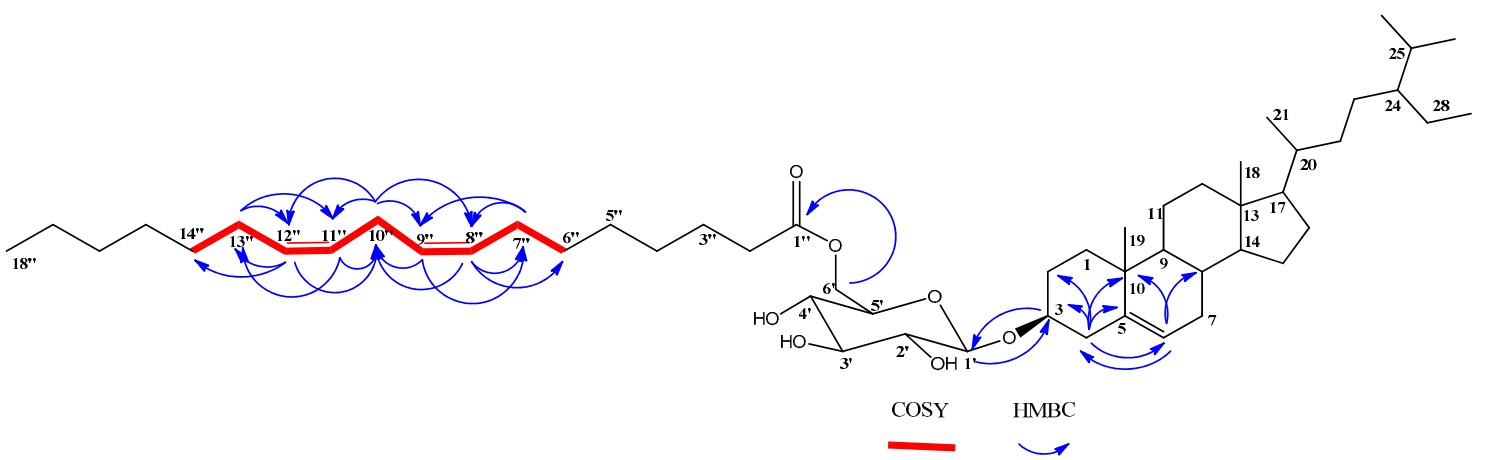

Figure 2. Selected HMBC and COSY correlations of compound 1.

The double bonds of the unsaturated fatty ester group are assigned as Z-configurations based on the previously published reports, which proved that the ${ }^{13} \mathrm{C}$ NMR chemical shifts of allylic methylene carbons $<28 \mathrm{ppm}$ in the case of $Z$ alkenes and $>30 \mathrm{ppm}$ in the case of $E$ ones $[18,19]$. Finally, to determine the exact length of the fatty acid chain, the compound was hydrolyzed, as mentioned in the experimental section, where the methylated fatty acid was subjected to GC-MS analysis. The results showed that 8,11-octadecadienoic acid-methyl ester was detected at $t_{R}=32.8$ and was identified and confirmed by the library (WileyRegi stry8e and mainlib). A final confirmation of the structure was obtained from HRMS analysis (positive mode) $\mathrm{m} / \mathrm{z}: 861.6581[\mathrm{M}+\mathrm{Na}]^{+}$. Based on the previous discussion, compound 1 was assigned as the (6'-O-octadeca- $8^{\prime \prime}, 11^{\prime \prime}$-dienoyl)-sitosterol-3-O- $\beta$-D-glucoside and reported here as a new natural product isolated for the first time from a natural source.

The six known compounds were identified through the analysis of the spectroscopic data, in addition to a comparison of their data with those previously presented in the literature, such as: stigmast-4-en-3-one (2) [20], 6- $\beta$-hydroxy-24-ethyl-cholest-4-en-3-one (3) [21], 6- $\alpha$-hydroxycholest-4-en-3-one (4) [22], $\beta$-sitosterol (5) [23,24], (6'-O-palmitoyl)-sitosterol-3-O- $\beta$-D-glucoside (6) [25], and $\beta$-sitosterol-3-O- $\beta$-D-glucoside (7) $[17,23]$. The structures of the six compounds are illustrated in Figure 3.

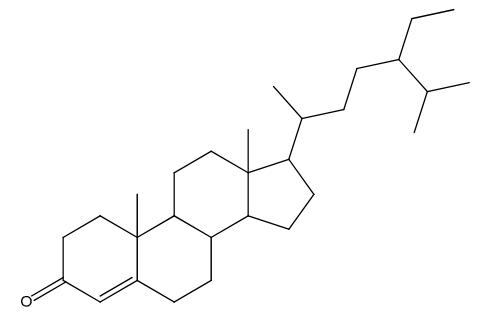

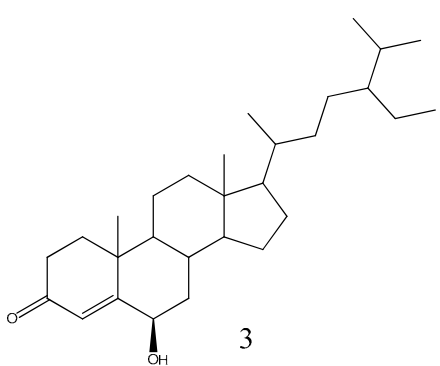

Figure 3. Cont. 


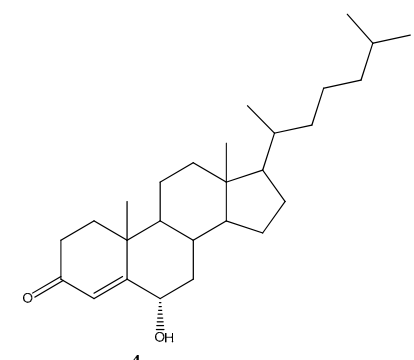

4

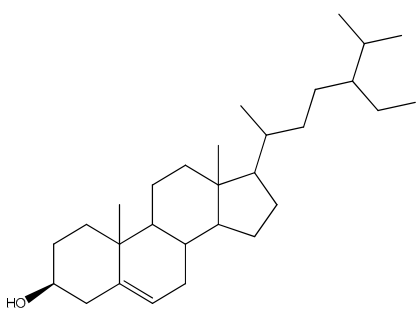

5

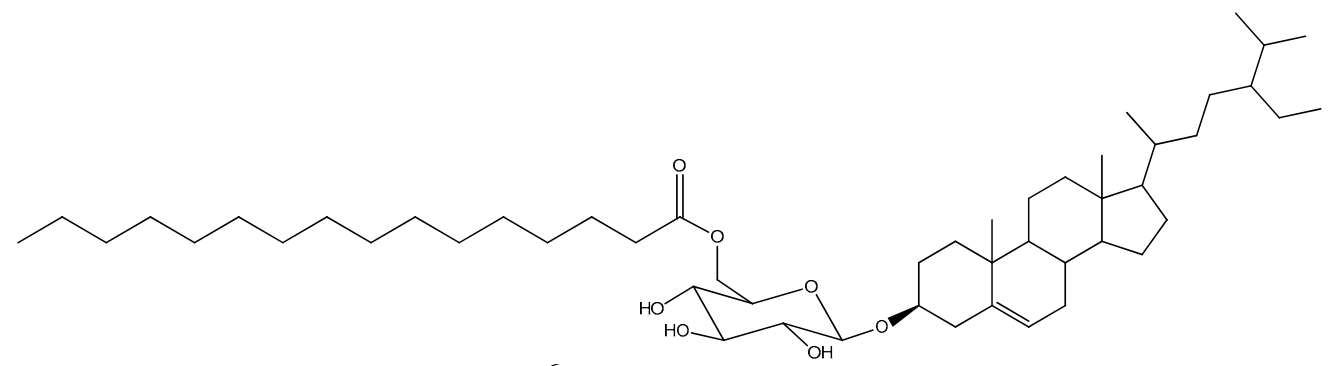

6

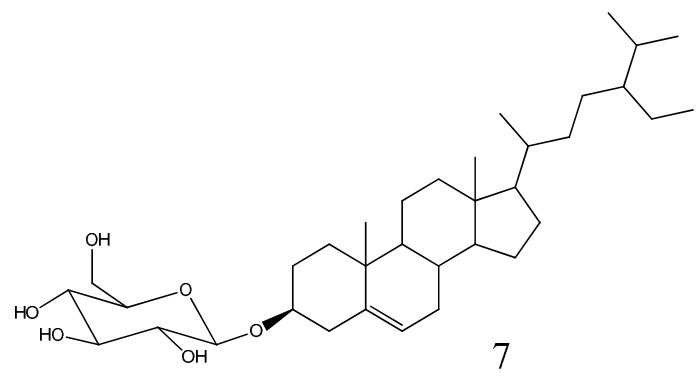

Figure 3. Structures of compounds 2-7.

2.2. Biological Evaluation of the Crude Extract and the Isolated Compounds

\subsubsection{Cytotoxic Assay}

Crude extracts, in addition to six sterol compounds, were screened for their cytotoxic activities against four cancerous cell lines: HepG2, Hela, A549, and MCF-7 and a noncancerous breast (MCF-10A) cell line to test their safety using the MTT assay (Table 2). The bamboo crude extract was most cytotoxic against the MCF-7 cell line $\left(\mathrm{IC}_{50}=38.8 \mu \mathrm{g} / \mathrm{mL}\right.$ ), with cell growth inhibition $63.4 \%$ at the highest concentration of $100 \mu \mathrm{g} / \mathrm{mL}$ (Figure 4), while it was safe against normal cells. After fractionation and isolation of the pure compounds, six compounds were tested for their cytotoxicity. Compound $\mathbf{1}$ was cytotoxic against the MCF-7 cells $\left(\mathrm{IC}_{50}=25.8 \mu \mathrm{M}\right)$ ore nearly the same as the 5-fluorouracil (5-FU) 26.98 $\mu \mathrm{M}$, and it was not toxic compared to 5-FU against the HepG2 cells $\left(\mathrm{IC}_{50}=27.52 \mu \mathrm{M}\right.$ compared to $15.8 \mu \mathrm{M})$. These results indicated that it was selective in its cytotoxic activity. Additionally, it was safe against the normal cells, with $\mathrm{IC}_{50} \geq 50$. Hence, compound $\mathbf{1}$ was assumed of value to be investigated in order to determine its impact on the induction of apoptosis in MCF-7 cancer cells. 
Table 2. Summarized $\mathrm{IC}_{50}$ of crude and identified sterol derivatives against four cancerous cell lines: HepG2, Hela, A549, and MCF-7 and normal cells.

\begin{tabular}{|c|c|c|c|c|c|}
\hline \multirow{2}{*}{ Tested Samples } & \multicolumn{5}{|c|}{$\mathrm{IC}_{50} \pm \mathrm{SD}(\mu \mathrm{g} / \mathrm{mL}) * \#$} \\
\hline & HepG2 & Hela & A549 & MCF-7 & $\begin{array}{c}\text { Normal Cells } \\
\text { MCF-10A }\end{array}$ \\
\hline Crude Extract & $48.4 \pm 1.32$ & $\geq 50$ & ND & $38.87 \pm 0.87$ & $\geq 50$ \\
\hline Pure Compounds & \multicolumn{5}{|c|}{$\mathrm{IC}_{50} \pm \mathrm{SD}(\mu \mathrm{M}) * \#$} \\
\hline 1 & $27.52 \pm 1.04$ & ND & ND & $25.82 \pm 1.04$ & \\
\hline 2 & ND & $32.45 \pm 0.89$ & $45.63 \pm 0.75$ & $\geq 50$ & \\
\hline 3 & ND & $\geq 50$ & $49.9 \pm 1.03$ & $\geq 50$ & \\
\hline 5 & $\geq 50$ & $42.32 \pm 1.02$ & $\geq 50$ & $\geq 50$ & $\geq 50$ \\
\hline 6 & $42.46 \pm 1.71$ & ND & ND & $\geq 50$ & \\
\hline 7 & $\geq 50$ & ND & ND & $38.05 \pm 0.98$ & \\
\hline 5-FU & $15.8 \pm 0.28$ & $13.04 \pm 0.65$ & $7.47 \pm 0.43$ & $26.98 \pm 0.76$ & \\
\hline
\end{tabular}

* Values are expressed as mean \pm SD of 3 independent trials $(n=3)$. ND is nondetermined. ${ }^{*} \mathrm{IC}_{50}$ were calculated using GraphPad Prism 7 software using a nonlinear regression dose-inhibition curve fit. 5-FU: 5- fluorouracil.

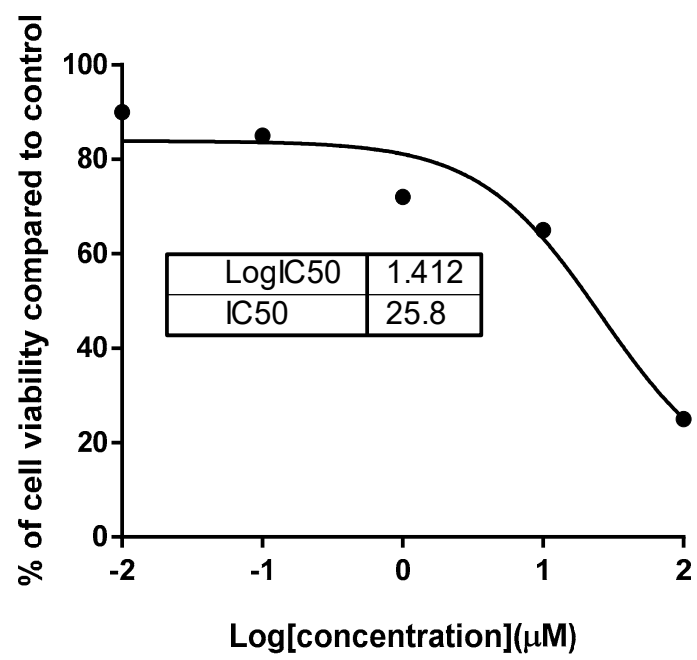

Figure 4. Nonlinear regression dose-inhibition curve fit of compound 1 against MCF-7 using GraphPad Prism 7 software.

\subsubsection{Apoptotic Investigation}

MCF-7 cancer cells were treated with compound $1\left(\mathrm{IC}_{50}=25.92 \mu \mathrm{M}, 48 \mathrm{~h}\right)$, which was investigated for its apoptosis-inducing activity using a flow cytometric analysis of Annexin V/PI staining and cell cycle analysis with the cell population in different cell cycle phases. As seen in Figure 5, upper panel, compound 1 significantly stimulated apoptotic breast cancer cell death 32.6 -fold (16.63\% compared to $0.51 \%$ for the control), while it stimulated cell death via necrosis 10.8 -fold ( $9.31 \%$ compared to $0.86 \%$ for the control). Moreover, MCF-7 cancer cells after compound 1 treatment were subjected to DNA flow cytometry to analyse the cell cycle kinetics to determine the compound's phase interference with the cell cycle. The study of the cell cycle is a crucial test showing the cell accumulation percentage in each growth phase with cytotoxic substances after treatment. As seen in Figure 5, lower panel, it increased the G2/M cell (26.74\% compared to $7.46 \%$ for the control) and pre-G1 (25.94\% compared to $1.37 \%$ for the control) populations; additionally, it decreased the cell population in S (24.95\% compared to $34.26 \%$ for the control). Consequently, compound 1 induced pre-G1 and G2/M-phase cell cycle arrest and blocked the progression of MCF-7 cancer cells that deteriorated the genetic material. 


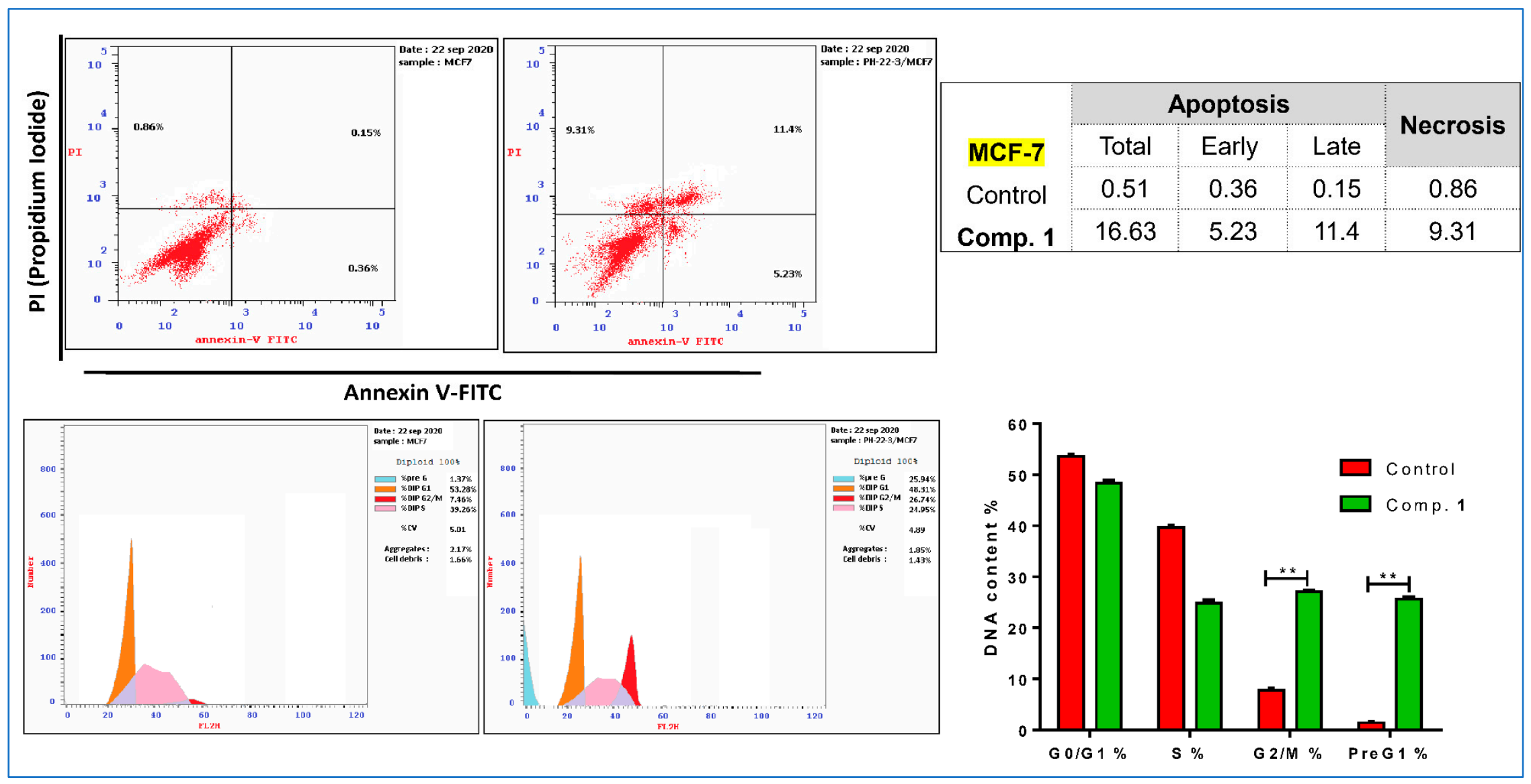

Figure 5. FITC/Annexin-V-FITC/PI differential apoptosis/necrosis (Upper panel) and DNA content flow cytometry-aided cell cycle analyses with bar chart representation (Lower panel) of both untreated and treated MCF-7 treated with compound $\mathbf{1}\left(\mathrm{IC}_{50}=25.92 \mu \mathrm{M}, 48 \mathrm{~h}\right.$ ). ${ }^{* *} p<0.05$ compared to the control. 


\section{3. $R T-P C R$}

For investigation of the apoptotic pathway, MCF-7 cells were treated with compound $\mathbf{1}$ $\left(\mathrm{IC}_{50}=25.92 \mu \mathrm{M}, 48 \mathrm{~h}\right)$; after this RNA was extracted, cDNA was synthesized, and the RT-PCR reaction was made to follow the mRNA expression of proapoptotic P53 and BAX; caspases 3, 8, and 9; and antiapoptotic gene Bcl-2. As shown in Figure 6, compound 1 significantly activated the level of the P53 gene ( $\approx 3.55$-fold), with concomitant activation of the BAX levels, with a maximum increase of 3.77-fold. The compound was able to significantly increase the mRNA levels of caspase 3, 8, and 9 genes with a maximum increase of $\approx 5.01$-fold, 1.9-fold, and 5.44-fold, respectively, while it significantly inhibited the antiapoptotic Bcl-2 gene (maximum decrease of $\approx 0.81$-fold). The results are in accordance with the proposed apoptotic pathway for anticancer activity.

\begin{tabular}{|l|l|l|l|l|l|}
\hline P53 & BAX & BCl2 & Casp-3 & Casp-8 & Casp-9 \\
\hline $3.55 \pm 0.28$ & $3.77 \pm 0.37$ & $0.81 \pm 0.05$ & $5.01 \pm 0.27$ & $1.9 \pm 0.13$ & $5.44 \pm 0.49$ \\
\hline
\end{tabular}

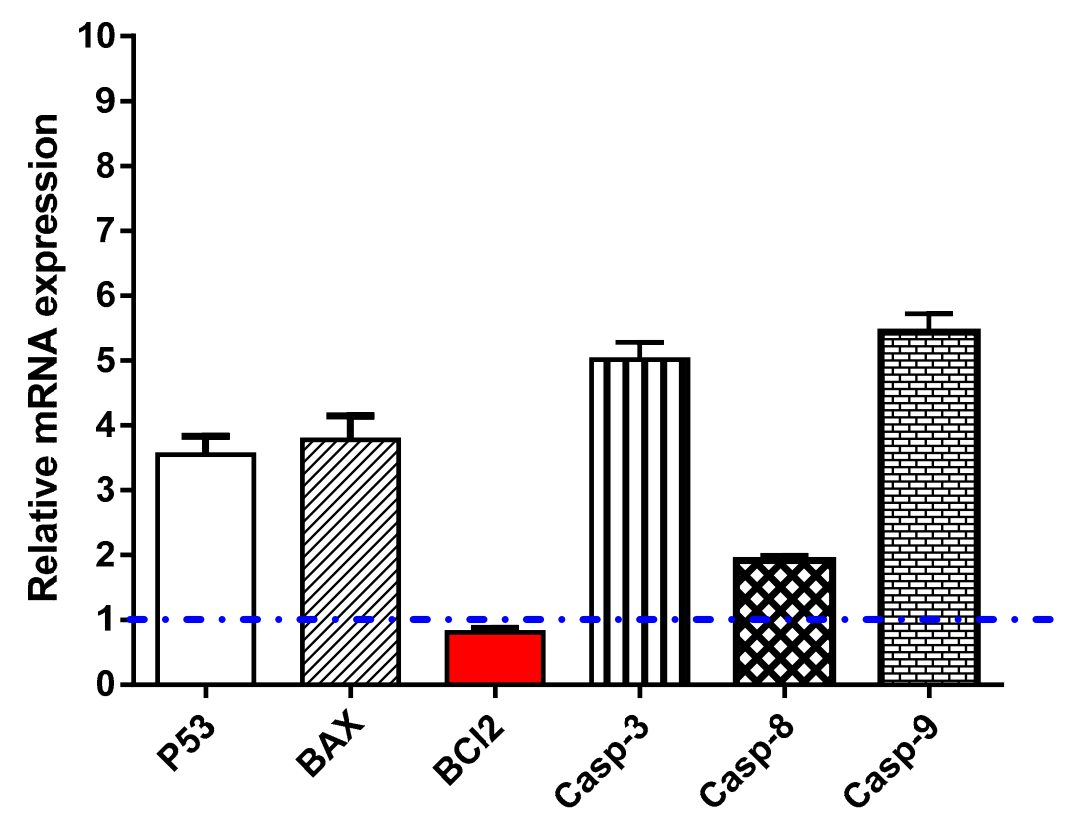

Figure 6. RT-PCR analysis of the apoptosis-related genes was performed after the MCF-7 cells were treated with compound $\mathbf{1}\left(\mathrm{IC}_{50}=25.92 \mu \mathrm{M}, 48 \mathrm{~h}\right)$.

\subsection{Molecular Docking}

Most of the examined compounds revealed significant activity against the human breast MCF-7 cancer cell line. We aimed to explore whether these compounds have a similar mechanism as the TPK and VEGFR-2 inhibitors. Accordingly, molecular docking was done to assess the binding energy, as well as the mechanism of the interaction of the compounds inside tyrosine-specific protein kinase (TPK) and vascular endothelial growth factor receptor (VEGFR-2) receptors. Compound 1 was docked inside the 1 T46 protein with a binding energy of $-78.58(\mathrm{Kcal} / \mathrm{mol})$, and it formed one hydrogen bond with a distance of $1.87 \AA$ through its $\mathrm{OH}$ group as Hydrogen bond acceptor (HBA) with Lys 623 as one of the key amino acid residues of the receptor-binding site. Additionally, it was docked inside the 1Y6A protein with a binding energy of $-24.56(\mathrm{Kcal} / \mathrm{mol})$, and it formed one hydrogen bond with a distance of $2.81 \AA$ through its $\mathrm{OH}$ group as HBA with Asn 921, which is the key amino acid for the binding interaction. Therefore, these molecular docking results suggested the dual activity of the tested derivatives as protein kinase/VEGFR-2 inhibitors, and this might propose the mechanistic mode of action for their cytotoxic activities (Table 3 and Figure 7). 
Table 3. Ligand receptor interactions of compound $\mathbf{1}^{\text {\# }}$ inside the tyrosine-specific protein kinase (TPK) (1T46) and vascular endothelial growth factor receptor (VEGFR-2) (1Y6A) targets. PDB: Protein Data Bank.

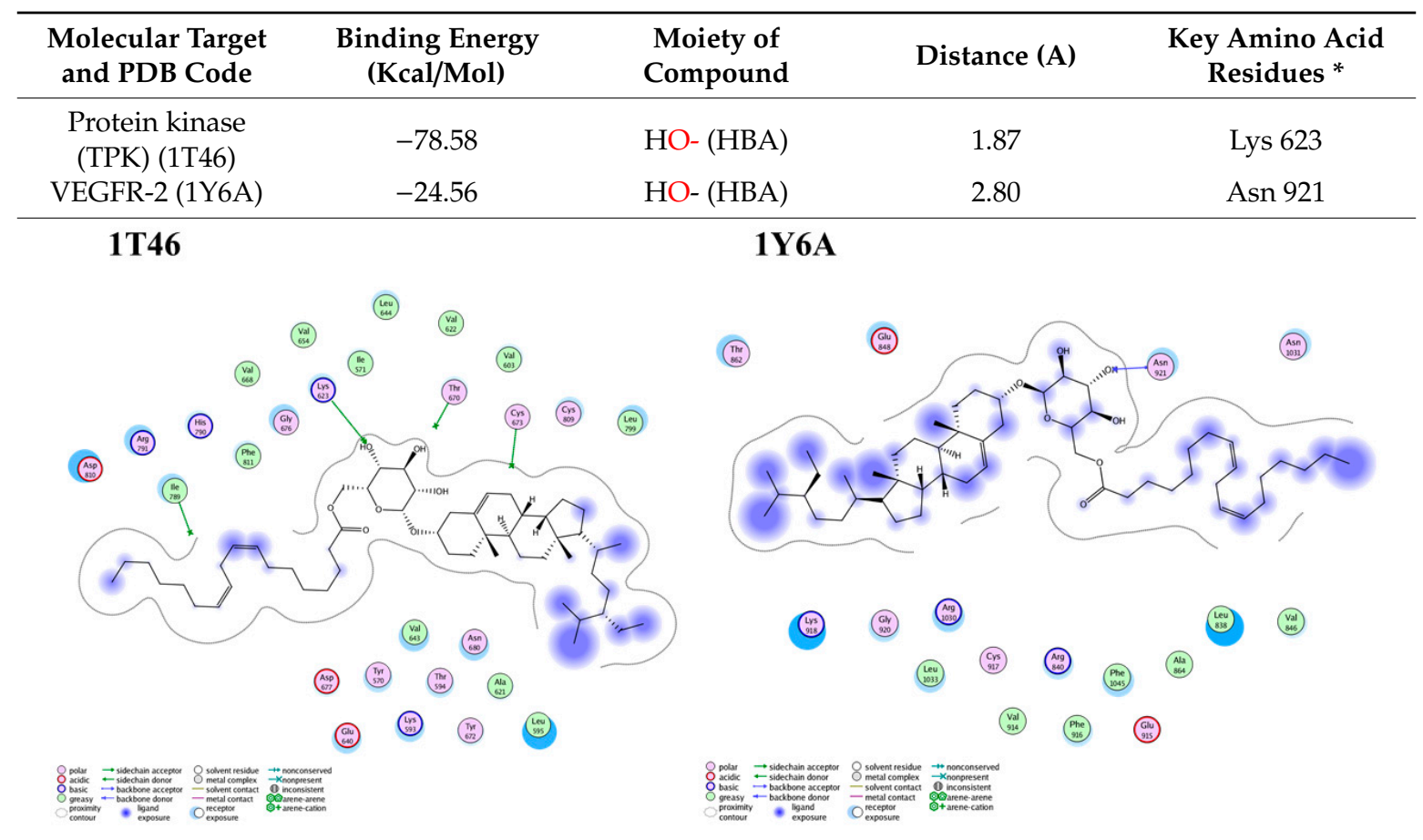

* Amino acids with which the co-crystallized ligand interacts inside the receptor-binding site. ${ }^{\text {\# }}$ Docking results of the rest of the compounds were supported as supplemental.

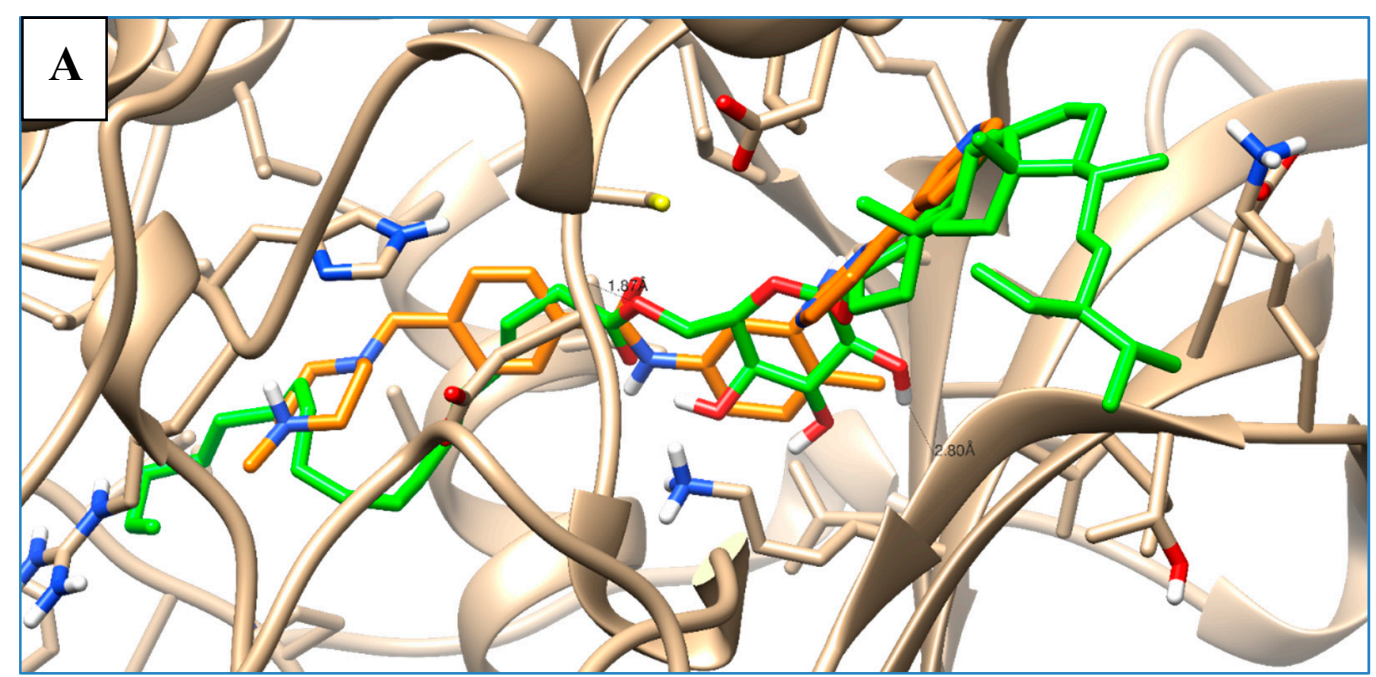

Figure 7. Cont. 


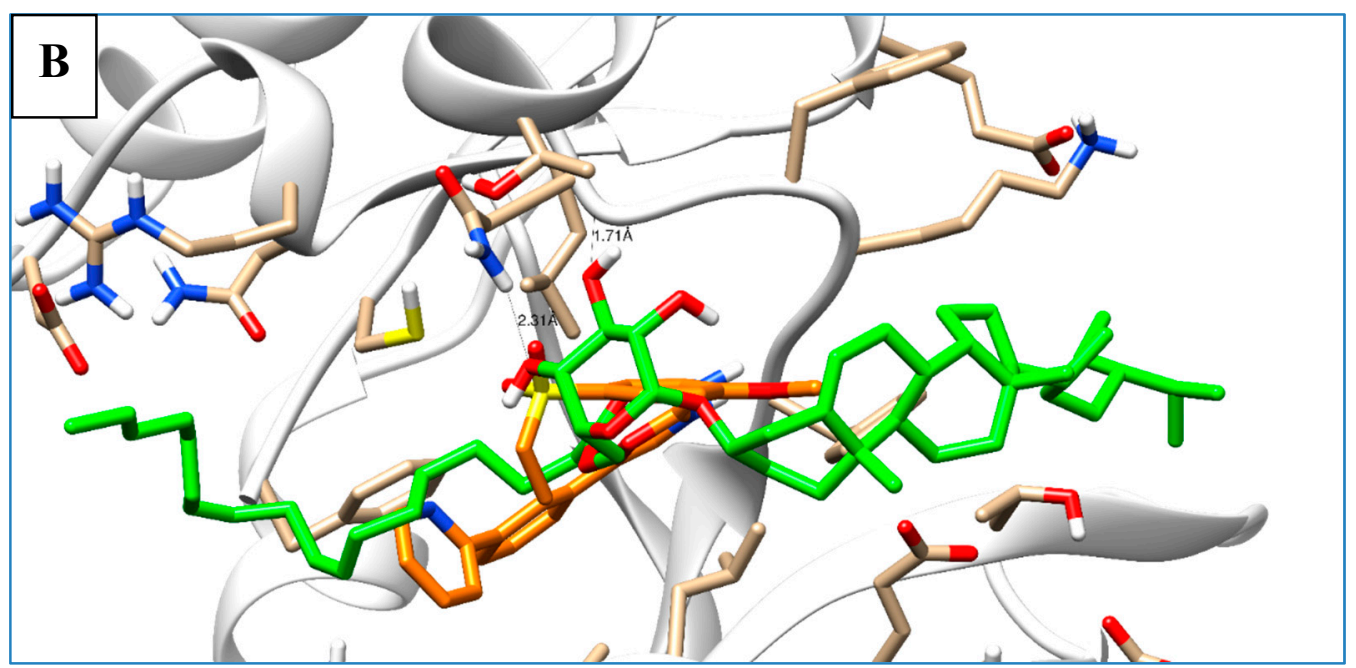

Figure 7. Superimposition of compound 1 (green) and the co-crystallized ligand (orange) inside both receptor-binding sites of the (A) tyrosine-specific protein kinase (TPK) (1T46) and (B) vascular endothelial growth factor receptor (VEGFR-2) (1Y6A).

\section{Experimental Section}

\subsection{General Experimental Procedures}

1D and 2D NMR spectra (chemical shifts in ppm and coupling constants in $\mathrm{Hz}$ ) were recorded on Bruker Avance DRX $500 \mathrm{MHz}$ spectrometers using deuterated pyridine as the solvent for compounds 1 and 7 and $\mathrm{CDCl}_{3}$ as the solvent for all other compounds. Column chromatographic separations were carried out using Sephadex LH-20 (0.25-0.1 mm, Pharmacia) and silica gel $60(0.04-0.063 \mathrm{~mm})$. TLC was accomplished using precoated TLC plates with silica gel 60 F254 (0.2 mm, Merck). Spots were visualized by UV absorption at $\lambda 255$ and $366 \mathrm{~nm}$, followed by spraying with P-anisaldehyde $/ \mathrm{H}_{2} \mathrm{SO}_{4}$. High-resolution mass spectroscopy (HRMS) was determined by direct injection using Thermo Scientific UPLC RS Ultimate 3000-Q. Exactive hybrid quadrupole-Orbitrap mass spectrometer combines high-performance quadrupole precursor selection with high resolution, accurate-mass (HR/AM) Orbitrap ${ }^{\mathrm{TM}}$ detection. Detection was in both positive and negative modes separately.

\subsection{Plant Material}

Moso bamboo (Phyllostachys heterocycla) was obtained from Japan. The plant was harvested in Isahaya, Nagasaki, Japan and collected on October 2011 and stored at $-24{ }^{\circ} \mathrm{C}$ until used. It was identified by Koji Yamada, Garden for Medicinal Plants, School of Pharmacy, Nagasaki University, Japan. A voucher specimen was deposited in the herbarium section of the Pharmacognosy Department, Faculty of Pharmacy, Suez Canal University, Ismailia, Egypt under registration number KY-11.

\subsection{Extraction and Purification of Compounds 1-7}

An amount of $12.7 \mathrm{Kg}$ was repeatedly extracted three times with methanol $(20 \mathrm{~L})$, followed by further extraction with $20 \mathrm{~L}$ of $\mathrm{CHCl}_{3}: \mathrm{MeOH}(1: 1)$ at room temperature, and the combined extracts were concentrated in vacuum using a rotary evaporator to give a residue of $110 \mathrm{~g}$. The residue was suspended in $\mathrm{H}_{2} \mathrm{O}(4 \mathrm{~L})$ and extracted with $n$-hexane, EtOAc, and $n$ - $\mathrm{BuOH}$, successively. The $n$-hexane extract $\left(37 \mathrm{~g}\right.$ ) was subjected to a $\mathrm{SiO}_{2}$ column and eluted using $n$-hexane: $\mathrm{CHCl}_{3}: \mathrm{MeOH}$ gradient. Three main fractions were investigated (fractions A, B, and C). Fraction A was further chromatographed to yield three main subfractions $(x, x x$, and $x x x)$. The subfraction $x$ was purified on silica gel column using isocratic elution with EtOAc: $n$-hexane (1:40), followed by purification on a Sephadex LH-20 column and eluted with $\mathrm{CHCl}_{3}: \mathrm{MeOH}$ (1:1) to yield a pure white powder of compound 2 (5.8 mg). The subfraction $x x$ was purified over a Sephadex LH-20 column and eluted with $\mathrm{CHCl}_{3}: \mathrm{MeOH}(1: 1)$, 
then, finally, purified on preparative TLC using EtOAc:n-hexane (1:3) to yield a pure white powder of compound $3(9.4 \mathrm{mg})$. The subfraction xxx was chromatographed over a $\mathrm{SiO}_{2} \mathrm{column}$, then over a Sephadex LH-20 column, and, finally, purified using preparative TLC using EtOAc:n-hexane (1:1) to yield a pure white powder of compound $4(0.3 \mathrm{mg})$. Fraction $\mathrm{B}$ was subjected to $\mathrm{SiO}_{2}$ column then over a Sephadex LH-20 column and eluted with $\mathrm{CHCl}_{3}: \mathrm{MeOH}(1: 1)$. Final purification was accomplished by recrystallization in $\mathrm{CHCl}_{3}: \mathrm{MeOH}$ (1:1) to yield pure crystalline needles of compound 5 (23.9 mg). Fraction $\mathrm{C}$ was fractionated over a $\mathrm{SiO}_{2}$ column using the $\mathrm{MeOH}: \mathrm{CHCl}_{3}$ gradient, then, finally, purified by crystallization in $\mathrm{CHCl}_{3}: \mathrm{MeOH}(1: 1)$ to yield the pure dark-yellowish waxy residue of compound $1(310.3 \mathrm{mg})$. The EtOAc extract was subjected to a SiO2 column and eluted with the $\mathrm{CHCl}_{3}: \mathrm{MeOH}$ gradient. Two main fractions (D and E) were obtained. Fraction D was further chromatographed on a Sephadex LH-20 using $\mathrm{CHCl}_{3} \mathrm{MeOH}(1: 1)$ as the eluent. Final purification was carried out by recrystallization in $\mathrm{CHCl}_{3}: \mathrm{MeOH}(1: 1)$ to afford the pure white powder of compound 6 (31 mg). Fraction E was chromatographed over a Sephadex LH-20 column and eluted with $\mathrm{CHCl}_{3}: \mathrm{MeOH}(1: 1)$, then purified by recrystallization in $\mathrm{CHCl}_{3}: \mathrm{MeOH}(1: 1)$ to yield the pure white powder of compound 7 (4.9 mg).

\subsection{Hydrolysis of Compound 1}

Compound (1) was hydrolyzed, and the free fatty acid was methylated by dissolving the compound in toluene $(1.2 \mathrm{~mL})$, methanol $(1.5 \mathrm{~mL})$, and then, $0.3 \mathrm{~mL}$ of $8 \% \mathrm{HCl}$ solution was added; the final solution was incubated at $45^{\circ} \mathrm{C}$ overnight and, then, the aqueous solution was fractionated against $n$-hexane, and methylated fatty acid was extracted in the organic layer and subjected to GC-MS analysis [26].

\subsection{Spectroscopic Data of the Isolated Compounds}

6'-O-octadeca-8",11"-dienoyl)-sitosterol-3-O- $\beta$-D-glucoside (1): dark-yellowish waxy residue. LC-HRMS analysis (positive mode) $m / z: 861.6581[\mathrm{M}+\mathrm{Na}]^{+}$, molecular formula: $\mathrm{C}_{53} \mathrm{H}_{90} \mathrm{O}_{7}, \mathrm{NMR}$ data: see Table 1.

Stigmast-4-en-3-one (2): white powder; ${ }^{13} \mathrm{C}-\mathrm{NMR}\left(125 \mathrm{MHz}, \mathrm{CDCl}_{3}\right): \delta_{\mathrm{C}} 35.7(\mathrm{C}-1), 33.9(\mathrm{C}-2), 199.7$ (C-3), 123.7 (C-4), 171.7 (C-5), 32.9 (C-6), 32.1 (C-7), 36.1 (C-8), 53.8 (C-9), 38.6 (C-10), 21.0 (C-11), 39.6 (C-12), 42.4 (C-13), 55.9 (C-14), 24.2 (C-15), 28.2 (C-16), 56.0 (C-17), 11.9 (C-18), 17.4 (C-19), 35.6 (C-20), 18.7 (C-21), 34.0 (C-22), 26.0 (C-23), 45.8 (C-24), 29.1 (C-25), 19.8 (C-26), 19.0 (C-27), 23.1 (C-28), 11.95(C-29).

6-Hydroxy-24-ethyl-cholest-4-en-3-one (3): white powder; ${ }^{13} \mathrm{C}-\mathrm{NMR}\left(125 \mathrm{MHz}, \mathrm{CDCl}_{3}\right): \delta_{\mathrm{C}} 37.1(\mathrm{C}-1)$, 34.3 (C-2), 200.6 (C-3), 126.3 (C-4), 168.6 (C-5), 73.3 (C-6), 38.6 (C-7), 29.7 (C-8), 53.6 (C-9), 38.0 (C-10), 21.0 (C-11), 39.6 (C-12), 42.5 (C-13), 56.1 (C-14), 24.1 (C-15), 28.2 (C-16), 55.9 (C-17), 12.0 (C-18), 19.5 (C-19), 36.1 (C-20), 18.7 (C-21), 33.9 (C-22), 26.1 (C-23), 45.8 (C-24), 29.1 (C-25), 19.8 (C-26), 19.0 (C-27), 23.1 (C-28), 12.0 (C-29).

6-Hydroxycholest-4-en-3-one (4): white powder; ${ }^{13} \mathrm{C}-\mathrm{NMR}\left(125 \mathrm{MHz}, \mathrm{CDCl}_{3}\right): \delta_{\mathrm{C}} 36.3(\mathrm{C}-1), 33.8(\mathrm{C}-2)$, 199.5 (C-3), 119.6 (C-4), 171.6 (C-5), 68.7 (C-6), 41.5 (C-7), 29.7 (C-8), 53.8 (C-9), 39.1 (C-10), 19.8 (C-11), 42.5 (C-12), 45.8 (C-13), 55.6 (C-14), 29.1 (C-15), 26.0 (C-16), 55.9 (C-17), 12.0 (C-18), 19.0 (C-19), 34.2 (C-20), 18.3 (C-21), 36.1 (C-22), 24.2 (C-23), 28.1 (C-24), 39.4 (C-25), 23.1 (C-26), 21.0 (C-27).

$\beta$-sitosterol (5): colorless needle crystals; ${ }^{13} \mathrm{C}-\mathrm{NMR}\left(125 \mathrm{MHz}, \mathrm{CDCl}_{3}\right): \delta_{\mathrm{C}} 37.3(\mathrm{C}-1), 31.9(\mathrm{C}-2), 71.8$ (C-3), 42.3 (C-4), 140.8 (C-5), 121.7 (C-6), 31.6 (C-7), 31.9 C-8), 50.1 (C-9), 36.5 (C-10), 21.1 (C-11), 39.8 (C-12), 42.3 (C-13), 56.8 (C-14), 24.3 (C-15), 28.3 (C-16), 56.1 (C-17), 11.9 (C-18), 19.1 (C-19), 36.2 (C-20), 18.8 (C-21), 33.9 (C-22), 26.1 (C-23), 45.8 (C-24), 29.1 (C-25), 19.8 (C-26), 19.4 (C-27), 23.1 (C-28), 12.0 (C-29). 
(6'-O-palmitoyl)-sitosterol-3-O- $\beta$-D-glucoside (6): white powder; ${ }^{13} \mathrm{C}-\mathrm{NMR}\left(125 \mathrm{MHz}, \mathrm{CDCl}_{3}\right): \delta_{\mathrm{C}} 37.3$ (C-1), 29.5 (C-2), 79.7 (C-3), 39.7 (C-4), 140.3 (C-5), 122.0 (C-6), 31.8 (C-7), 31.9 (C-8), 50.1 (C-9), 36.1 (C-10), 21.0 (C-11), 38.8 (C-12), 42.3 (C-13), 56.7 (C-14), 24.3 (C-15), 28.2 (C-16), 56.1 (C-17), 11.8 (C-18), 19.0 (C-19), 36.6 (C-20), 18.7 (C-21), 33.9 (C-22), 29.1 (C-23), 45.7 (C-24), 26.1 (C-25), 19.3 (C-26), 19.7 (C-27), 23.0 (C-28), 11.9 (C-29), $101.2\left(\mathrm{C}-1^{\prime}\right), 73.6\left(\mathrm{C}-2^{\prime}\right), 76.3\left(\mathrm{C}-3^{\prime}\right), 70.5\left(\mathrm{C}-4^{\prime}\right), 73.2\left(\mathrm{C}-5^{\prime}\right), 63.9\left(\mathrm{C}-6^{\prime}\right)$, 174.2 (C-1"), 34.3 (C-2"), 25.0 (C-3"), 29.3-29.9 (C-4": C-14"), 22.6 (C-15"), 14.1 (C-16").

$\beta$-sitosterol-3-O- $\beta$-D-glucoside (7): white powder; ${ }^{13} \mathrm{C}-\mathrm{NMR}\left(125 \mathrm{MHz}, \mathrm{C}_{5} \mathrm{D}_{5} \mathrm{~N}\right): \delta_{\mathrm{C}}(37.3) \mathrm{C}-1,30.0$ (C-2), 78.2 (C-3), 39.7 (C-4), 140.7 (C-5), 121.7 (C-6), 32.0 (C-7), 31.8 (C-8), 50.1 (C-9), 36.7 (C-10), 21.1 (C-1), 39.1 (C-12), 42.3 (C-13), 56.6 (C-14), 24.3 (C-15), 28.4 (C-16), 56.0 (C-17), 11.8 (C-18), 19.2 (C-19), 36.2 (C-20), 18.8 (C-21), 34.0 (C-22), 26.1 (C-23), 45.8 (C-24), 29.2 (C-25), 19.8 (C-26), 19.0 (C-27), 23.2 (C-28), 12.0 (C-29), $102.3\left(\mathrm{C}-1^{\prime}\right), 75.1\left(\mathrm{C}-2^{\prime}\right), 78.3\left(\mathrm{C}-3^{\prime}\right), 71.4\left(\mathrm{C}-4^{\prime}\right), 78.0\left(\mathrm{C}-5^{\prime}\right), 62.5\left(\mathrm{C}-6^{\prime}\right)$.

\subsection{Biological Evaluation of the Compounds}

\subsubsection{Cytotoxic Activity}

Crude extract, together with six of the identified sterols, were screened for their cytotoxic activities against liver HepG2, breast MCF-7, and normal cells (MCF-10A), as well. According to the standard cell culture work $[27,28]$, each cell line was cultured in a proper complete medium. The treatment of cells was performed with the crude extract and then, with the identified compounds for a 48-h incubation, and Fluorouracil (5-FU) was used as the standard. Percent of cell viability was calculated by the following formula: \% cell viability $=$ (Mean absorbance of tested compound)/(Mean absorbance in control) $\times 100$. Then, $\mathrm{IC}_{50}$ in $\mu \mathrm{M}$ was calculated using GraphPad Prism 7 .

\subsubsection{Apoptotic Investigation Using Flow Cytometric Analysis}

Cell cycle analysis, as well as apoptotic assays, were performed in detail according to the previously described methods [29-31]. Full methodologies of flow cytometric assays were provided in the Supplementary File. After treatment with compound $1\left(\mathrm{IC}_{50}=25.92 \mu \mathrm{M}, 48 \mathrm{~h}\right)$, the harvested MCF-7 cells were subjected to flow cytometric analyses, including FITC/Annexin-V-FITC/PI differential apoptosis/necrosis assessment, and DNA content flow cytometry-aided cell cycle analysis, to define in which phase cells would be arrested and to estimate the percentage of apoptotic cells.

\subsubsection{RT-PCR Assay}

MCF-7 cells were treated with compound $1\left(\mathrm{IC}_{50}=25.92 \mu \mathrm{M}, 48 \mathrm{~h}\right)$. At the end of treatments, cells were collected, and total RNA was extracted using a RNeasy ${ }^{\circledR}$ Mini Kit (Qiagen, Hilden, Germany) according to the manufacturer's instructions. cDNA synthesis was performed with $500 \mathrm{ng}$ of RNA using the i-Script cDNA synthesis kit (Bio-Rad, Hercules, CA, USA) following the manufacturer's instructions. Real-time (RT)-PCR reactions consisted of $25-\mu \mathrm{L}$ Fluocycle ${ }^{\circledR} \mathrm{II}$ SYBR ${ }^{\circledR}$ (Euroclone, Milan, Italy), $1.5 \mu \mathrm{L}$ of both $10-\mu \mathrm{M}$ forward and reverse primers, $3-\mu \mathrm{L} c \mathrm{DNA}$, and $19 \mu \mathrm{L}$ of $\mathrm{H}_{2} \mathrm{O}$. All reactions were performed for 35 cycles using this temperature profile: $95^{\circ} \mathrm{C}$ for $5 \mathrm{~m}$ (initial denaturation); $95^{\circ} \mathrm{C}$ for $15 \mathrm{~min}$ (Denaturation), $55{ }^{\circ} \mathrm{C}$ for $30 \mathrm{~min}$ (Annealing), and $72{ }^{\circ} \mathrm{C}$ for $30 \mathrm{~min}$ (Extension) [32,33]. Then, The cycle threshold $(\mathrm{Ct})$ values were collected and the relative folds of changes between all the samples. Primer used were listed in the Supplementary Files.

\subsection{In Silico Molecular Docking}

As a trial to elucidate the cytotoxic activity profile exhibited by the compounds under investigation, molecular docking was performed between the studied compounds as ligands with tyrosine-specific protein kinase (TPK; PD: 1T46) and vascular endothelial growth factor receptor (VEGFR-2; PD:1Y6A). The molecular modeling studies were implemented using a computational software basis (MOE 2008-10, Chemical Computing Group, Montreal, QC, Canada), as regards the tested proteins whose 
crystal structures complexed with their co-crystallized ligands were easily accessible from the Protein Data bank. Basis of modeling concerning receptor and ligand preparation and molecular docking were achieved according to Nafie et al., 2019 [34,35]. Each ligand-receptor complex was examined for the binding interaction analysis.

\section{Conclusions}

Phytochemical screening of nonpolar extracts of the bamboo shoot skin Phyllostachys heterocycla resulted in the isolation of the new compound (6'-O-octadeca- 8 ", $11^{\prime \prime}$-dienoyl)-sitosterol-3-O- $\beta$-D-glucoside, together with six known sterols. The new compound showed potent cytotoxic effects against the MCF-7 cells $\left(\mathrm{IC}_{50}=25.8 \mu \mathrm{M}\right)$. It significantly stimulated apoptotic breast cancer cell death 32.6 -fold (16.63\% compared to $0.51 \%$ for the control) at the pre-G1 and G2/M-phase cell cycle arrest and blocked the progression of MCF-7 cells. Moreover, the RT-PCR results further confirmed the apoptotic activity of compound $\mathbf{1}$ by the upregulation of proapoptotic genes (P53; Bax; caspases 3, 8, and 9) and downregulation of the antiapoptotic genes (BCL2). Finally, molecular docking studies could declare the mode of action of the tested compounds, as they were found to have a high binding affinity towards both TPK and VEGFR-2, where the new compound 1 possessed the highest affinity.

Supplementary Materials: The following are available online. Full characterization charts $\left({ }^{1} \mathrm{HNMR},{ }^{13} \mathrm{CNMR}\right.$, DEPT-135, COSY, HMBC, HSQ C, and mass spectroscopy) of the new compound, molecular docking files, and results are supported as a Supplementary File.

Author Contributions: R.F.A.A. and K.Y. conceived and designed the experiment; K.Y. collected and identified the plant material; R.F.A.A., A.K.I. (Ahmed K. Ibrahim), and E.S.H. performed the experiments, including isolation and structure elucidation of the pure compounds; M.S.N. performed cytotoxic activity using the MTT assay, Annexin-V/PI staining, cell cycle analysis, RT-PCR, and molecular modeling; M.S.A.-K. conducted the spectral analysis of the pure compounds; S.A.A., R.F.A.A., and M.S.N., writing-original draft; and J.M.B. and A.K.I. (Amany K. Ibrahim), writing-review and editing. All authors have read and agreed to the published version of the manuscript.

Funding: This research received no external funding.

Acknowledgments: This publication was supported by the Deanship of Scientific Research at Prince Sattam Bin Abdulaziz University, Alkharj, Saudi Arabia, as well as Suez Canal University, Ismailia, Egypt.

Conflicts of Interest: The authors declare no conflict of interest.

\section{References}

1. Yuming, Y.; Kanglin, W.; Shengji, P.; Jiming, H. Bamboo Diversity and Traditional Uses in Yunnan, China. Mt. Res. Dev. 2004, 24, 157-165. [CrossRef]

2. Nirmala, C.; David, E.; Sharma, M.L. Changes in nutrient components during ageing of emerging juvenile bamboo shoots. Int. J. Food Sci. Nutr. 2007, 58, 612-618. [CrossRef] [PubMed]

3. Chongtham, N.; Bisht, M.S.; Haorongbam, S. Nutritional Properties of Bamboo Shoots: Potential and Prospects for Utilization as a Health Food. Compr. Rev. Food Sci. Food Saf. 2011, 10, 153-168. [CrossRef]

4. Tanaka, A.; Shimizu, K.; Kondo, R. Antibacterial compounds from shoot skins of moso bamboo (Phyllostachys pubescens). J. Wood Sci. 2013, 59, 155-159. [CrossRef]

5. Park, H.-S.; Lim, J.H.; Kim, H.J.; Choi, H.J.; Lee, I.-S. Antioxidant flavone glycosides from the leaves of Sasa borealis. Arch. Pharm. Res. 2007, 30, 161-166. [CrossRef] [PubMed]

6. Park, E.-J.; Jhon, D.-Y. The antioxidant, angiotensin converting enzyme inhibition activity, and phenolic compounds of bamboo shoot extracts. Lw-Food Sci. Technol. 2010, 43, 655-659. [CrossRef]

7. Zhang, Y.; Jiao, J.; Liu, C.; Wu, X.; Zhang, Y. Isolation and purification of four flavone C-glycosides from antioxidant of bamboo leaves by macroporous resin column chromatography and preparative high-performance liquid chromatography. Food Chem. 2008, 107, 1326-1336. [CrossRef]

8. Ishii, T.; Hiroi, T.; Thomas, J.R. Feruloylated xyloglucan and p-coumaroyl arabinoxylan oligosaccharides from bamboo shoot cell-walls. Phytochemistry 1990, 29, 1999-2003. [CrossRef] 
9. Kweon, M.-H.; Hwang, H.-J.; Sung, H.-C. Identification and Antioxidant Activity of Novel Chlorogenic Acid Derivatives from Bamboo (Phyllostachys edulis). J. Agric. Food Chem. 2001, 49, 4646-4655. [CrossRef]

10. Keski-Saari, S.; Ossipov, V.; Julkunen-Tiitto, R.; Jia, J.; Danell, K.; Veteli, T.; Guiquan, Z.; Yaowu, X.; Niemelä, P. Phenolics from the culms of five bamboo species in the Tangjiahe and Wolong Giant Panda Reserves, Sichuan, China. Biochem. Syst. Ecol. 2008, 36, 758-765. [CrossRef]

11. Suga, A.; Takaishi, Y.; Goto, S.; Munakata, T.; Yamauchi, I.; Kogure, K. Two lignan dimers from bamboo stems (Phyllostachys edulis). Phytochemistry 2003, 64, 991-996. [CrossRef]

12. Takahashi, T.; Mizui, K.; Miyazawa, M. Volatile compounds with characteristic odour in moso-bamboo stems (Phyllostachys pubescens Mazel ex Houz. De ehaie). Phytochem. Anal. 2010, 21, 489-495. [CrossRef] [PubMed]

13. Panee, J. Potential Medicinal Application and Toxicity Evaluation of Extracts from Bamboo Plants. J. Med. Plant. Res. 2015, 9, 681-692. [CrossRef] [PubMed]

14. Tanaka, A.; Zhu, Q.; Tan, H.; Horiba, H.; Ohnuki, K.; Mori, Y.; Yamauchi, R.; Ishikawa, H.; Iwamoto, A.; Kawahara, H.; et al. Biological activities and phytochemical profiles of extracts from different parts of bamboo (Phyllostachys pubescens). Molecules 2014, 19, 8238-8260. [CrossRef] [PubMed]

15. Kim, K.K.; Kawano, Y.; Yamazaki, Y. A novel porphyrin photosensitizer from bamboo leaves that induces apoptosis in cancer cell lines. Anticancer Res. 2003, 23, 2355-2361.

16. Lv, Y.; Li, M.; Liu, T.; Tong, L.; Peng, T.; Wei, L.; Ding, J.; Xie, H.; Duan, W. Discovery of a New Series of Naphthamides as Potent VEGFR-2 Kinase Inhibitors. ACS Med. Chem. Lett. 2014, 5, 592-597. [CrossRef]

17. Peshin, T.; Kar, H.K. Isolation and Characterization of $\beta$-Sitosterol-3-O- $\beta$ - D-glucoside from the Extract of the Flowers of Viola odorata. Br. J. Pharm. Res. 2017, 16, 1-8. [CrossRef]

18. Zeng, X.; Li, C.-Y.; Wang, H.; Qiu, Q.; Qiu, G.; He, X. Unusual lipids and acylglucosylsterols from the roots of Livistona chinensis. Phytochem. Lett. 2013, 6, 36-40. [CrossRef]

19. Su, B.-N.; Takaishi, Y. Morinins H-K, Four Novel Phenylpropanol Ester Lipid Metabolites from Morina chinensis. J. Nat. Prod. 1999, 62, 1325-1327. [CrossRef]

20. Rosandy, A.R.; Kamal, N.M.; Talip, N.; Khalid1, R.; Abu Bakar, M. Isolation of four steroids from the leaves of fern Adiantum latifolium Lam. Malays. J. Anal. Sci. 2017, 21, 298-303.

21. Arai, Y.; Nakagawa, T.; Hitosugi, M.; Shiojima, K.; Ageta, H.; Basher, O. Abdel-Halim Chemical constituents of aquatic fern Azolla nilotica. Phytochemistry 1998, 48, 471-474. [CrossRef]

22. Li, L.-Y.; Deng, Z.-W.; Fu, H.-Z.; Li, J.; Lin, W.-H.; Proksch, P. 6-Hydroxy-4-en-3-one sterols from the marine sponge Iotrochoto birotulata. J. Asian Nat. Prod. Res. 2005, 7, 115-120. [CrossRef] [PubMed]

23. Goad, J.; Akihisa, T. Analysis of Sterols; Springer: Amsterdam, The Netherlands, 1997; ISBN 978-0-7514-0230-8.

24. Chaturvedula, V.S.P.; Prakash, I. Isolation of Stigmasterol and $\beta$-Sitosterol from the dichloromethane extract of Rubus suavissimus. Int. Curr. Pharm. J. 2012, 1, 239-242. [CrossRef]

25. Chaurasia, N.; Wichtl, M. Sterols and Steryl Glycosides from Urtica dioica. J. Nat. Prod. 1987, 50, 881-885. [CrossRef]

26. Ichihara, K.; Fukubayashi, Y. Preparation of fatty acid methyl esters for gas-liquid chromatography. J. Lipid Res. 2010, 51, 635-640. [CrossRef]

27. Tantawy, E.S.; Amer, A.M.; Mohamed, E.K.; Abd Alla, M.M.; Nafie, M.S. Synthesis, characterization of some pyrazine derivatives as anti-cancer agents: In vitro and in Silico approaches. J. Mol. Struct. 2020, 1210, 128013. [CrossRef]

28. Khodair, A.I.; Alsafi, M.A.; Nafie, M.S. Synthesis, molecular modeling and anti-cancer evaluation of a series of quinazoline derivatives. Carbohydr. Res. 2019, 486, 107832. [CrossRef]

29. Nafie, M.S.; Arafa, K.; Sedky, N.K.; Alakhdar, A.A.; Arafa, R.K. Triaryl dicationic DNA minor-groove binders with antioxidant activity display cytotoxicity and induce apoptosis in breast cancer. Chem. Biol. Interact. 2020, 324, 109087. [CrossRef]

30. Gad, E.M.; Nafie, M.S.; Eltamany, E.H.; Hammad, M.S.A.G.; Barakat, A.; Boraei, A.T.A. Discovery of New Apoptosis-Inducing Agents for Breast Cancer Based on Ethyl 2-Amino-4,5,6,7-Tetra Hydrobenzo[b]Thiophene-3-Carboxylate: Synthesis, In Vitro, and In Vivo Activity Evaluation. Molecules 2020, 25, 2523. [CrossRef]

31. Nafie, M.S.; Amer, A.M.; Mohamed, A.K.; Tantawy, E.S. Discovery of novel pyrazolo[3,4-b]pyridine scaffold-based derivatives as potential PIM-1 kinase inhibitors in breast cancer MCF-7 cells. Bioorg. Med. Chem. 2020, 28, 115828. [CrossRef] 
32. Nafie, M.S.; Mahgoub, S.; Amer, A.M. Antimicrobial and antiproliferative activities of novel synthesized 6-(quinolin-2-ylthio) pyridine derivatives with molecular docking study as multi-targeted JAK2/STAT3 inhibitors. Chem. Biol. Drug Des. 2020. [CrossRef] [PubMed]

33. Sarhan, A.A.M.; Boraei, A.T.A.; Barakat, A.; Nafie, M.S. Discovery of hydrazide-based pyridazino[4,5- b ]indole scaffold as a new phosphoinositide 3-kinase (PI3K) inhibitor for breast cancer therapy. RSC Adv. 2020, 10, 19534-19541. [CrossRef]

34. Nafie, M.S.; Tantawy, M.A.; Elmgeed, G.A. Screening of different drug design tools to predict the mode of action of steroidal derivatives as anti-cancer agents. Steroids 2019, 152, 108485. [CrossRef] [PubMed]

35. Youssef, E.; El-Moneim, M.A.; Fathalla, W.; Nafie, M.S. Design, synthesis and antiproliferative activity of new amine, amino acid and dipeptide-coupled benzamides as potential sigma-1 receptor. J. Iran. Chem. Soc. 2020, 17, 2515-2532. [CrossRef]

Sample Availability: Samples of all compounds are not available from the authors.

Publisher's Note: MDPI stays neutral with regard to jurisdictional claims in published maps and institutional affiliations.

(C) 2020 by the authors. Licensee MDPI, Basel, Switzerland. This article is an open access article distributed under the terms and conditions of the Creative Commons Attribution (CC BY) license (http://creativecommons.org/licenses/by/4.0/). 